Article

\title{
Fragmentation and Cooperation in the Jihadi International (Sub)System: 'Islamic State' vs. Al-Qaeda and Beyond
}

\author{
Marina Eleftheriadou \\ Department of Political Science and International Relations, University of Peloponnese, GR-20132 Corinth, \\ Greece; m.elef@cemmis.edu.gr
}

Received: 27 February 2020; Accepted: 31 March 2020; Published: 3 April 2020

\begin{abstract}
The article explores the implications the rise of the 'Islamic State' (IS) had on the international order and the salafi-jihadi movement. The main argument is that at the height of its activity (2014-2016) IS was a de facto revolutionary state. In this capacity, IS challenged the international order because contrary to revolutionary states in the past it negated the foundations of the Westphalian system. At the same time, the rise of IS had a tremendous impact on the jihadi (sub)system, as it initiated a period of fragmentation and alliance-building. The competition between IS and al-Qaeda for the hegemony of the movement did not revolve around direct fighting as much as efforts to outbid the rival group. One of the main conduits of this competition was the 'war of bay'as (pledges of allegiance)', which consisted of competitive oaths of allegiance from local jihadi forces to one of the two groups. In local contexts, the 'war of bay'as' increased tensions and factionalism within jihadi groups, as splinter groups decided to side with the new revolutionary foco. The fragmentation of local jihadi groups unfolded along pre-existing cleavages, grievances and resource-related motivations, increasing the levels of violence and complexity in these local conflicts.
\end{abstract}

Keywords: 'Islamic State'; al-Qaeda; alliances; competition; fragmentation; international order; revolutionary state

\section{Introduction}

In July 2014, the entire world watched in shock and disbelief Abu Bakr al-Baghdadi declare the restoration of the 'Caliphate'. Today, al-Baghdadi is dead, and the Caliphate has been reduced to a (imaginary) shell. However, despite its current status, the 'Islamic State' (IS) merits a deeper exploration, for its impact and repercussions have been profound and far-reaching. IS's violent entrance in the global scene has shuttered much of our understanding of violent non-state actors and the salafi-jihadi movement in particular. For years the common wisdom was that the jihadi movement (and particularly al-Qaeda) had undergone an organizational transformation in the wake of the 'war on terrorism', evolving from a relatively hierarchical group to a deterritorialized network that preferred attacking the West than controlling territory. Yet, in mid-2014, IS demonstrated that jihadi groups do not mind controlling territory, if given the opportunity.

However, IS's impact has been larger than simply invalidating the main premise of the 'new wars' paradigm. As this article shows, the declaration of the Caliphate and the extent of IS's territorial control raise important questions in the study of international politics. Was IS, at the height of its activity in 2014-2016, a terrorist group, a guerrilla movement or a revolutionary state? The answer to this question will help us understand the nature of IS's challenge to the global order. If IS (and possible future copycats) are able to socialize into the international system's norms, as other revolutionary states in the past did, then the international community might consider a more conciliatory response. 
On the contrary, if IS's ideology and strategic considerations preclude this type of groups to become 'normal' members of the international community, conciliatory gestures will have a limited impact, no matter how generous they are.

The meteoric rise of IS did not rattle only the international system, but it had a profound impact on the salafi-jihadi movement as well. The salafi-jihadi (sub)system, as the article shows, underwent an intense period of competition and alliance-building. This competition primarily involved IS and al-Qaeda, which competed for hegemony in the jihadi movement. Drawing on Watts's (2016) distinction between 'destructive' and 'escalating competition', the article explores the phases of IS-al-Qaeda rivalry. However, contrary to Watts, the article posits that destructive competition, in terms of direct conflict between al-Qaeda and ISIS has been in reality limited, even where they have been the closest, Syria. Instead, as the article shows, the rivalry has been played out in three domains: propaganda, attacks on western targets and a 'war of bay'as', which is the main focus of this article. Prominent ideologues and jihadi groups around the world were called to take a stance on the al-Qaeda-IS conflict. Many felt the need to situate themselves on the new jihadi map, either reiterating their loyalty to al-Qaeda or siding with the new-comer. This resulted in a flurry of competitive pledges of oath coming from all the corners of the jihadi movement. This war of bay'as has ushered a period of turmoil in the jihadi subsystem. The process of system recalibration took the form of international alliance-building and local fragmentation, which affected most local jihadi scenes and conflicts.

The article explores the challenge IS posed to the international system and the jihadi subsystem as follows. The first section provides a brief theoretical discussion of fragmentation and alliance-building in violent non-state groups. The theoretical propositions discussed in this section are then used to inform the examination of IS and its competition with al-Qaeda. The exploration of IS's challenge is expounded in three parts. The first of the three examines the nature of IS's challenge to the international order by asking what type of actor IS (or the Caliphate) was at the height of its activity, what was its stance towards the international system, and conversely, what was the stance of the international community towards IS. The second part explores the repercussions of IS's claim to hegemony within the jihadi movement by tracing the roots and mechanisms of al-Qaeda-IS competition and identifying the main conduits of intra-jihadi rivalry at the highest level. The last part opens the focus to include IS-inspired intra-movement competition and fragmentation at the local level, highlighting the motivations behind (splinter) groups' decision to pledge allegiance (bay'a) to Abu Bakr al-Baghdadi.

\section{Friends or Foes? Alliance-Building and Fragmentation in Non-State Armed Groups}

Militant groups ally and feud like every other political actor. Of the two, intra-group competition and factionalism is easier to pinpoint. Internal fragmentation or 'fratricide' (Hafez 2017; Staniland 2012) occurs when groups that belong to the same movement 'start targeting each other through words and/or actions' (Hamming 2020, p. 14). Competition between groups has been linked to higher lethality, as the effort to 'outbid' rival groups leads to more violence (Bakke et al. 2012; Conrad and Greene 2015) and suicide terrorism (Bloom 2005), especially in religious and nationalist movements (Nemeth 2014).

Alliances, on the other hand, are harder to define because not all alliances are equal. The most concise definition of alliances draws from the International Relations (IR) theory and defines alliances as 'formal or informal collaborative arrangements between two or more actors who employ terrorist tactics in the pursuit of joint interests' (Moghadam 2017, p. 7). In reality, cooperation might take various forms: ideological, logistical and operational (Jadoon 2018; Karmon 2005; Phillips 2019). In the context of the IS-al-Qaeda rivalry, ideological cooperation might take the form of a public pledge of allegiance. Logistical cooperation involves sharing material and/or non-material resources, such as weapons, funds, training, consultations and propaganda assistance. Operational cooperation refers to cooperation in the preparation or execution of attacks.

Groups might forge collaborative arrangements in one or more fields. The more cross-sectional and intensive the cooperation the deeper the alliance. Alliances can take four (ideal) forms: mergers, strategic alliances, tactical cooperation, and transactional cooperation (Jadoon 2018; Moghadam 2015). 
At the lower end of cooperation, groups enter into a marriage of convenience to fulfil short-term and narrow goals. Limited in nature and scope, this cooperation is driven by practical rather than ideological goals. High-end cooperation, on the other hand, involves cooperation in more than one domain. These alliances, which range from strategic alliances to mergers and full absorption of the weaker group, constitute the highest form of alliance building between militant groups.

The scholarship on alliance-formation between violent non-state groups agrees on one point: alliances are rare (Asal et al. 2016, pp. 6-7; Byman 2014, p. 438; Oots 1989, p. 144). If anything, fragmentation is the norm. The rarity of alliances 'does not make them uninteresting' (Oots 1989, p. 145), though. Alliances have been associated with higher lethality (Asal and Rethemeyer 2008; Oots 1989), the adoption of suicide bombing tactics (Asal et al. 2016) and the prospect of pursuing CBRN weapons (Asal et al. 2012). Given their rarity but high impact, there are two overriding questions: what makes non-state alliances so hard in the first place and what motivations make groups overcome these obstacles and forge alliances against 'common sense'. Answers to these questions can be grouped under two broad categories. The first group includes studies that rest on material consideration and organizational imperatives to explain alliances (and fragmentation) in armed non-state groups. The second category contains studies that, to a varying extent, acknowledge the importance of power considerations but, at the same time, place more emphasis on ideology and shared framing in the formation and deepening of alliances.

The study of alliance formation in non-state conflicts has built on various theoretical traditions. The most daring drew from IR theory and particularly balance of power or balance of threat theories. Karmon (2005), for instance, has demonstrated the relevance of neorealist concepts and balance-of-threat alliance-building theories in the study of terrorist groups' (international) cooperation. In the same vein, Christia (2012) has demonstrated the centrality of power considerations in civil war alliances, in tandem with realist expectations as the author admits. Indeed, as some scholars have noted, non-state groups often face similar conditions of anarchy as states in the international system (Adamson 2005, pp. 43-44; Christia 2012, p. 51; Fearon 1995; Posen 1993). The lack of institutions to mitigate uncertainty and suspicion attenuates commitment issues in non-state alliance formation (Bacon 2014, p. 5; Christia 2012, p. 6). The inability of non-state groups to enforce commitment, due to the nature of their operations, renders power considerations central to their outcome. Although state sponsors can on occasions act as external enforcers, increasing overall trust and predictability (Bapat and Bond 2012), in general, the lower the degree of institutionalization within movements, the higher the possibility of fragmentation and infighting if there are changes in the distribution of power (Bakke et al. 2012).

Organizational issues and concerns have been the focus of numerous studies which, instead of IR theory, draw insights from businesses cooperation or organizational theory (Bacon 2018; Byman 2014; Horowitz and Potter 2014). Along the lines of realist-inspired literature, these studies downplay ideology in favor of resources-related considerations. Militant groups align to procure tangible and intangible resources to increase their overall capabilities. By forming alliances, groups might expect direct assistance in the form of funds and weapon transfers or training opportunities, especially if the ally holds territory. Groups with transnational aspirations might seek alliances to gain access to local resources, people and local terrain's knowledge (Byman 2014, p. 431; Jadoon 2018, p. 31). Intangible resources, on the other hand, might take the form of 'best practices' sharing (Cragin et al. 2007), as groups might benefit from the transfer of new information, technology and tactics (Asal et al. 2016; Horowitz 2010). Some groups might also want to associate themselves with an established group to improve their credibility, legitimacy and prestige or to exploit the opportunity to 're-invent their image' (Bacon 2014, pp. 4, 8). This is most evident in groups with acute organizational learning or adaptation needs that for various reasons cannot undertake self-reform to address their problems (Bacon 2014, p. 16). The notion of weakness as a driver for alliance-building is contested (Phillips 2019). Some studies consider (effective) state counterinsurgency and military losses as an important motivation for groups to seek allies (Kalyvas and Kocher 2007). Well-placed allies can offer the struggling group territory and networks to weather the storm. Al-Qaeda's reliance on Taliban's safe houses and trusted 
networks after US intervention in Afghanistan is a case in point (Bacon 2014, p. 8). On the contrary, Bapat and Bond (2012) claim that weak groups might seek alliances but their inability to withstand counterterrorism pressure turns them into undesirable partners.

In this turmoil of competing arguments, ideology-based studies pose a simple counter-argument: groups ally (or fragment) for ideological reasons. Drawing from scholarship on state alliances (Barnett 1996; Holsti et al. 1973), these studies posit that a shared enemy and shared ideology affect partner selection (Asal et al. 2016; Gade et al. 2019). Given that groups operate in an anarchic and unpredictable environment, ideological homophily might improve the levels of trust among groups and institute commonly accepted norms and preferences. Agreement on the basics, such as conflict framing, conception of the ideal polity, and territorial aspirations (Gade et al. 2019), might smoothen the path to alignment.

Walt (1987) has demonstrated that some ideologies are extremely divisive to allow alliance formation. Therefore, ideology is most likely to play an important role in alliance formation when this ideology is unifying, not divisive. Drawing from Walt, Karmon (2005) identifies nationalistic ideologies as the least accommodating to inter-group cooperation and anarcho-communist ideologies as the most prone to forge alliances. Nationalistic ideologies are by nature exclusionary and territorially bounded, characteristics that diminish the attractiveness of alliances. On the opposite side, the main characteristic that encouraged the formation of coalitions between groups that ascribed to anarcho-communism was their fluid and decentralized ideological base (Karmon 2005, p. 42). Religious ideologies, which Karmon touches only briefly, can offer similar encompassing and decentralized ideological bases. Indeed, relevant research has shown that groups that share religious affiliation are particularly likely to form alliances (Asal et al. 2016; Phillips 2019).

The article sustains that the main difference of religious ideologies is that the latter can be divisive locally but unifying globally. Religious groups often adopt exclusionary views towards competitive forces in their immediate circle of operations. The inherent centralization imperative in religious ideologies, such as salafi-jihadism, and competition over local resources and recruits fuel intra-field rivalries and fragmentation. At the same time, religious groups often ascribe to a transnational and transcendental understanding of community. Therefore, they aspire to speak in the name of a global community of faithful that recognizes no borders. Often lacking the capacity to reach these global communities, religious groups choose to forge alliances with local same-minded forces. International alliances of this kind are possible because the two parties do not 'compete in the same primary political and resource market'(Bacon 2014) and they have fewer things to worry about.

\section{The 'Islamic State' against the World}

\subsection{The 'Caliphate' Enters the Westphalian Order}

Every study of IS and its self-proclaimed 'Caliphate' inevitably stumbles upon the fundamental question of how best approach the 'Islamic State' entity and the global jihadi movement in general. IS has global interests and nearly global reach, to a degree that few militant organizations had in the past, including al-Qaeda. Contrary to al-Qaeda, though, IS has 'presented' the international community with its version of being a state. In this capacity, IS has operated simultaneously in two systems: the international-Westphalian-system and the jihadi (sub)system. From mid-2014 until 2016, IS controlled more than 100,000 square kilometers of territory and a population of over 11 million people (Jones et al. 2017), which were governed through sophisticated administrative structures. In this regard, it was larger, more populous and better-governed than many contemporary states. This raised the question if we should continue treating IS as a terrorist organization or the concept of a (revolutionary) state is more appropriate (Rich 2016; Walt 2015) and if that is the case what should be the stance of the international community.

Previous research on revolutionary states has shown that revolutionary states have a deep impact on the international system, either by increasing the possibility of international conflict 
(Maoz 1996; Walt 1996) or by challenging and occasionally changing the norms and logic of the established international order (Armstrong 1993; Halliday 1999). The aim of revolutionary groups is not only to seize power, but to radically change also the socio-political relations and the society. This aim is not restricted to the domestic front. It involves the international society as well. By the same token, revolutionary regimes perceive the international order under a Manichean prism; a struggle between the forces of 'good and evil, rich and poor, oppressed and oppressors, old and new' (Armstrong 1993, p. 197). Often guided by a teleological view of world politics, they do not consider themselves bound by the established rules, putting forward instead notions of 'universal society' and world revolution (Halliday 1999). Hence, an inherent feature of revolutionary states is their aspiration to export their revolution, either through conquest or by providing an inspirational example for others to copy (Walt 2015). This aspiration is equally guided by their ideological convictions and the need to strengthen the regime internally by finding scapegoats for their troubles (Maoz 1996).

These dynamics are readily evident in the 'Islamic State'. The basic tenet of IS's conceptualization of territoriality rests on the conviction that the 'rebirth of the ummah and the caliphate ... require deterritorializing and dismantling the colonial geopolitical heritage and its national borders and nation states and reterritorializing the ummah and caliphate' (Jabareen 2015, p. 53). Indeed, IS has, on several occasions, rejected any obstacle (be it nationalism or factionalism) that stands in the way of a united ummah (Dabiq 2015d, pp. 3-6). As al-Baghdadi stated in 2012: 'the Islamic State does not recognize synthetic borders, nor any citizenship besides Islam' (Bunzel 2015, p. 24). In other words, IS believes that no aspects of territorial sovereignty, such as 'borders... passports or visas' (Dabiq 2014, p. 23) might limit its global claims to 'Makkah and al-Madīnah ... Baytul-Maqdis and Rome' (Dabiq 2014, p. 3). Therefore, it does not see itself as part of and does not have any 'commitments towards the international community' (Al-Shishani 2014). In this light, all states but the Islamic State are considered illegitimate.

Nevertheless, the ideological fervor of revolutionary states and their effort to change the international order is reciprocated by intense structural pressures to 'socialize' in the same norms and logic they abhor (Armstrong 1993; Walt 1992). In order to secure their survival and protect themselves from internal and external counter-revolution forces, they need to engage in international trade and find allies. At the same time, the fact that they have to run a state ironically forces them to resort and legitimize the international norms and tools that safeguard sovereignty and by extent the international order (Armstrong 1993, p. 302). Indeed, when IS state-project came under western military attack in 2014, IS appeared to contemplate some type of socialization within the international system's norms. The conditions of this socialization are outlined in a series of articles, authored by the captured journalist John Cantlie (Dabiq 2015a, pp. 48-50; 2015d, pp. 64-67). Exploring the conditions for a respite in IS's war against the western countries, Cantlie draws on previous examples of revolutionary states, such as Bolshevik Russia and Maoist China, but stops short of foregoing IS's aspirations of global revolution. The editorial note on one of Cantlie's articles clearly states that IS could offer the West nothing more than a temporary truce (Dabiq 2015d, p. 67). Its ideological rigidity, notwithstanding, the IS has an additional characteristic that renders its socialization in the international system more problematic. Contrary to other revolutionary states, it was not established within the borders of an existing state, but from the start it was a transnational project that covered parts of both Iraq and Syria, without though overthrowing either of the ruling regimes.

Given the revolutionary logic and the formative conditions of IS, the question that remains is whether the international order will choose to accommodate such as state or find ways to destroy it. Vu and Van Orden (2019) employ a three-pronged test to examine IS's 'suitability' for incorporation in the international order: power capabilities, shared values and self-destructive tendencies. They claim that, first, IS was not powerful enough and did not have a powerful patron to 'force' the international community to accept the reality of its existence. Second, ISIS shared no values whatsoever with Western societies. Hence, there was no common ground that could ease IS into the international order with the prospect of future moderation, as happened for example in the case of Iran. Third, IS's extremism was 
inherently self-destructive as it alienates possible allies and the local population. Hence, as the authors predicted IS was doomed to self-destroy.

IS's extremism and inherent contradictions lied at the heart of discussions around the stance the international community should assume vis-à-vis the IS and the best possible strategy for dismantling its state. One approach was containment. The idea behind this strategy was that IS's ideology was too parochial to inspire a revolutionary wave and in any case it was not as powerful as many feared to warrant a military intervention, which could inadvertently strengthen the resolve of its supporters and boost its prestige (Walt 2015, p. 42). At the same time, though, its existence was too damaging to simply be left alone, as is the case for other de facto states, such as Somaliland. Instead, IS was bound to fail because its economy and its state model was unsustainable in the long run. Hence, the best strategy was to contain and isolate it, while applying subtle pressure through local and regional forces to heighten its contradictions and accelerate its demise. Clint Watts (2015) proposed a similar approach, which he dubbed a 'let them rot' strategy. Drawing from the experience of Algerian forces in dismantling the enclaves of the Groupe Islamique Armé (GIA) during the Algerian civil war, he claimed that by actively preventing the formation of these jihadist states, one allows the preservation of Sharia governance dream. Instead, if we allow them to form, the proponents of such a state will see that after all it is not the utopia they dreamed.

Both scholars, however, highlighted some requirements for this strategy to work, which were absent or were difficult to implement in the specific context, such as the relatively large territory of IS's state, the inability of local and international forces to provide alternatives to demobilized fighters, the lack of consensus within the international coalition and the diverging interests of neighboring states and regional powers (Walt 2015, p. 46; Watts 2015, pp. 159-61). Most importantly, perhaps, this strategy required patience, which was difficult to sustain in the wake of terrorist attacks in Europe and increasing refugee flows. Western powers deemed that the time needed to contain and gradually degrade IS was politically not viable, opting instead for an intensification of air raids, while arming and training local (Kurdish) forces for ground operations against the IS.

\subsection{Fratricide in the Jihadi Sub-System: The Rift between IS and Al-Qaeda}

The threat of compromising its global brand does not only concern IS's authority and interaction with the international-Westphalian—system, but also the jihadi (sub)system. In his study of jihadi pro-states, Brynjar Lia (2015) claims that one of the main characteristics of jihadi de facto states is that they are all intensely ideological and internationalist projects. Guided by the ideological imperative to establish Sharia and alter the border-delimitated world order, jihadi proto-states, like IS, often prefer to 'sacrifice state building on the altar of ideological purity'. According to Lia, two interlinked factors may explain this reluctance to forego their ideological rigidity: first, the dependence of jihadi proto-states on external constituencies, namely foreign fighters and donors, and second, their competition with rival jihadi groups (Lia 2015, p. 37). In other words, a jihadi proto-state needs to preserve its ideological edge to keep competition in check and attract more fighters and resources than its competitors.

Building on Lia's argument, this article claims that, above all, IS's rise constitutes a bid for increased power and influence vis-à-vis rival Islamist groups. The Caliphate was not restored in an ideological void or organizational vacuum. IS built on a long history and legacy of state-building paradigms within the salafi-jihadi movement (Lia 2015, pp. 34-35). By being the first one to venture building an 'Islamic State' of this magnitude and Islamic connotations, IS poses a direct challenge to other groups within the jihadi sub-system. The challenge is most direct towards the other jihadi claimant to a global brand, al-Qaeda.

The intra-movement rift between the so-called Islamic State and al-Qaeda was not the first one to rock the jihadi scene, but to this day, it has been the most spectacular. The beginning of the crisis can be traced to al-Baghdadi's decision, in April 2013, to move the forces of Islamic State in Iraq (ISI) into Syria and announce a merge with Jabhat al-Nusra. In Baghdadi's eyes, ISI was merely subduing a jihadi group, that he had sent to Syria, and which lately had been showing signs of disobedience 
(Hassan 2018, pp. 3-4). In the eyes of al-Nusra's leader, Abu Muhammad al-Julani, this was a violent take-over, which threatened his and his group's survival. In the eyes of the new al-Qaeda leader, Ayman al-Zawahiri, it was a direct challenge to al-Qaeda's long-held position as the main jihadi hub and brand within the jihadi movement.

Al-Qaeda has a long history of internal disagreements and tense relations with affiliates. These internal tensions have been documented in al-Qaeda's long bureaucratic log of organizational blueprints and lengthy letter-exchanges. Studies of captured internal documents have identified several dividing lines within the wider salafi-jihadi movement, such as the divide between 'strategists' and 'doctrinaires', the global/local and the global/classical dichotomies (Lahoud et al. 2012; Moghadam and Fishman 2010). As a bureaucratic organization, al-Qaeda has been plagued also by financial quarrels, power struggles over recruits and territory and local leadership ambitions, which are exacerbated by the geographical distance and poor communication (Brachman and McCants 2006; Brown 2007; Byman 2014; Hamming 2019). The jihadi movement has also a history of internal fighting and cases of local forces going rogue. However, neither the fratricide that followed the Soviet withdrawal from Afghanistan nor the ultra-violent spree of GIA during Algeria's civil war (Hamming 2019) managed to stir the jihadi scene as much as Abu Bakr al-Baghdadi. Al-Baghdadi's demonstration of disrespect towards al-Qaeda was built on a history of often strenuous relations between al-Qaeda central and its Iraqi affiliate. However, despite some suggestions within the leadership core, Osama bin Laden never considered severing ties with its first leader, Abu Musab al-Zarqawi.

What was different in Baghdadi's challenge that forced al-Zawahiri to expel the group from al-Qaeda's ranks? According to Hagerty (2016), the relationship between al-Qaeda and its Iraqi affiliate hinges on four parameters: the levels of strategic cohesion, need fulfillment, trust, and communication between the two. Although the two groups never shared a common strategic outlook, their affiliation fulfilled some needs for both al-Qaeda and al-Zarqawi. Al-Qaeda gained a vigorous group that kept the organization relevant after post-9/11 setbacks. Al-Zarqawi, on the other hand, gained an affiliation with the al-Qaeda brand and the access this offered to recruits and sources of funding (Hagerty 2016, p. 15). Contrary to al-Zarqawi, Al-Baghdadi assumed that al-Qaeda no longer fulfilled the group's needs and that, after bin Laden's death, there was room for a new brand. The strategic 'misunderstanding' between the two was further fueled by the diminishing levels of trust and communication, both exacerbated by the geographic distance that separated the two groups.

Nevertheless, the al-Qaeda-ISIS rift was more than a misunderstanding. Access to new resources and recruitment opportunities in the Syrian conflict, offered ISIS the additional material incentives to disassociate itself from al-Qaeda. The Syrian civil war allowed ISIS much more maneuvering room for empowerment, compared to al-Qaeda leadership, which is long entrapped in the Af-Pak borderland. This change in the distribution of power within the jihadi movement spearheaded a re-balancing act, gradually turning the unipolar jihadi subsystem into an -aspiring-bipolar one. In the process, the jihadi subsystem entered a period of turbulence that eventually engulfed the entire movement.

According to Clint Watts (2016), the ISIS-al-Qaeda competition has gone through two distinct phases. The first, covering the period from summer 2013 until mid-2014, was dominated by 'destructive competition', that is competition centered around direct violence between the adversaries. After ISIS's march through Nineveh and the declaration of the Caliphate in Mosul, competition between the two has shifted to 'escalating'. Escalating competition largely resembles the outbidding strategy, which is often used by competing militant groups in an effort to outpace their adversaries. This transition, according to Watts, was made possible by the stabilization of the intra-jihadi territorial borders in Syria, which allowed the two adversaries to 'swivel their weapons outward ... solidifying their stake in a crowded global jihadist landscape' (Watts 2016, p. 3). Hamming (2017) agrees with the distinction, but claims that the first phase of the al-Qaeda-ISIS competition involved both destructive and escalating features.

This article posits that destructive competition, in terms of direct conflict between al-Qaeda and its Syrian affiliate and ISIS, was in reality limited. Apart from some skirmishes and localized fighting, the lion's share of anti-ISIS violence came from local jihadi forces, such as Ahrar al-Sham (as Islamic 
Front), rather than al-Qaeda affiliated al-Nusra (Bunzel 2014). The jihadi movement suffered from weak institutions, yet the degree of institutionalization within the movement, at least in terms of informal norms, routines, customs, and traditions (Bakke et al. 2012, p. 269), was high enough to prevent high-level fighting. Indeed, al-Zawahiri and a number of al-Qaeda affiliated ideologues, such as al-Maqdisi and Abu Qatada, initially stroke a didactic, yet conciliatory, tone in their messages to ISIS. The tone started to change after ISIS killed al-Nusra's emir in Raqqa and particularly after the assassination of Abu Khalid al-Suri, a founding member of Ahrar al-Sham and a prominent jihadi in Syria (Hamming 2017, pp. 74-75; Lahoud and Al-Ubaydi 2014, p. 4). In response, Al-Qaeda went as far as severing official ties and dubbing ISIS a Khawarij ${ }^{1}$ group (Jackson 2014); still though, both al-Nusra and al-Qaeda stopped short of calling for violence against ISIS, advocating the use of violence only as last resort (Hamming 2020, pp. 10-11; Skovgaard-Petersen 2017, pp. 30-31).

ISIS was not as chivalrous. Verbal attacks against al-Qaeda became all more explicit after Baghdadi's rebuttal of Zawahiri's 'ruling' in favor of al-Nusra. In Baghdadi's words, he had to 'chose the order of God over the orders that contravenes Allah in the letter [of al-Zawahiri]'. A year later, Baghdadi stood at the pulpit of Mosul's Grand al-Nuri Mosque to announce the restoration of the Caliphate. Although ISIS often flirted with the notion of takfir (excommunication) against al-Qaeda, it crossed the line only in the end of 2015, when an article featured in ISIS journal Dabiq (no.12), titled 'The Allies of al-Qa'ida in Sham: the End', explicitly called al-Nusra apostate (Hamming 2017, p. 75). By that time, however, intra-jihadi fighting in Syria had largely ceased and the competition had shifted to global outbidding.

After the declaration of Caliphate, ISIS shed the geographical references in its name, and as 'Islamic State' (IS) shifted its focus to the global propagation of the newly-created Caliphate and its new brand. IS's foray into the global scene was three-pronged. First, an outward propaganda campaign that took by storm the internet, raising eyebrows inside the jihadi online community and the western media. Building on previous efforts to modernize jihadi propaganda-namely al-Qaeda in the Arabian Peninsula (AQAP) journal Inspire-IS media production became the new golden standard in online propaganda. Sleek, edited down-to-the-detail and flirting with internet culture (e.g., memes) and gaming aesthetics, IS propaganda was selling a new-and competitive to al-Qaeda—brand and a new methodology (manhaj) to disgruntled Muslims around the world. This was a glaring effort on IS's part to outbid al-Qaeda in attracting recruits. Contrary though to al-Qaeda, IS had a 'state' to present to possible recruits, offering thus the option of 'civilian hijra' (immigration to the Caliphate), besides the career of 'foreign fighter'. IS made every effort to highlight this difference with al-Qaeda, often featuring scenes of serene daily life under the 'Islamic State' in its propaganda.

The second prong of IS's hegemony quest in the jihadi sub-system was the escalation of attacks on western countries. One possible explanation for the surge of IS-related attacks in western capitals is the international coalition's attacks on IS in Syria and Iraq. This explanation, which sees the rise of IS violence as a reaction to western attacks on its 'state', is supported by the fact that the rate of terrorist plots increased after the anti-IS coalition was formed and that countries actively participating in the coalition's operations were targeted to a larger extent (Nesser 2019, pp. 17-18). That was also the reasoning that IS's spokesman al-Adnani used to call for attacks against Europe in a number of statements issued in that period (Nesser et al. 2016, p. 5). Another possibility is that IS-related violence was a reaction to the efforts of some western countries to close the 'gates of hijra'. In this sense, tighter border controls and the implementation of travel restrictions on possible recruits have forced some to resort to domestic terrorism. IS's publications and Al-Adnani's statements, on occasions, explicitly referred to the increasing difficulties recruits faced in their effort to reach the Caliphate, urging them instead to conduct attacks against civilians in their countries of residence (Al-Adnani 2016;

1 Khawarij was the first dissident group within Islam. It was formed after the death of Prophet Muhammad expressing disagreements on how Muhammad's successor should be chosen. In Islamic parlance it has come to denote extremism and it is considered a very serious accusation. 
Dabiq 2015c, p. 54). A third explanation, and closer to this article's argument, is that this surge of terrorist attacks also constituted an open effort to outbid al-Qaeda on its preferential field: attacks on the far-enemy (Watts 2016). In this regard, the escalation of IS violence against western countries is essentially directed towards its jihadi antagonist, al-Qaeda, which has been long advocating attacks on the West, but lately has been having problems delivering such attacks.

The third conduit of al-Qaeda-IS competition took the form of a 'war of bay'as'. Prominent ideologues and jihadi groups around the world were called to take a stance on the al-Qaeda-IS conflict. Many felt the need to situate themselves on the new jihadi map, either reiterating their loyalty to al-Qaeda or siding with the new-comer. This resulted in a flurry of competitive pledges of oath; including Zawahiri, who renewed his oath to Mullah Omar and, when the death of Mullah Omar was announced, to his successor, Mullah Mansour. This war of bay'as ushered a period of alliance re-building in the jihadi movement. This process of system recalibration, local fragmentation and alliance-building, which affected most local jihadi scenes and conflicts, is explored in more detail in the following section.

\subsection{After the 'War of Words', the 'War of Bay'as': Alliance-Building and Fragmentation in the Age of the 'Caliphate'}

ISIS spokesperson, Abu Muhammad al-Adnani, had in effect announced the restoration of the Caliphate few weeks before al-Baghdadi's caliph-like appearance in Mosul. In his speech, al-Adnani stated that 'with this declaration of the caliphate, it is incumbent upon all Muslims to pledge allegiance to the Caliph Ibrahim and support him'. In the same vein, al-Adnani added that "the legality of all emirates, groups, states, and organizations becomes null by the expansion of the caliph's authority and arrival of its troops to their areas' (Al-Adnani 2014). The declaration of the Caliphate, thus, automatically posed a question of authority and allegiance; theoretically to all Muslims, but practically to the other groups in the jihadi movement.

With the help of technology, Adnani's call for bay'as ${ }^{2}$ reached the edges of the jihadi world. In a climate of heated debate, a flurry of online bay'as ensued. At that point, most of them were personal bay'as on social media (Holtmann 2014). Increasingly, though, collective baya's from jihadi groups started coming in. Since 2014, more than 40 groups, spanning an area from west Africa to southeast Asia, have pledged an oath of allegiance to al-Baghdadi. IS has displayed less restraint than al-Qaeda in accepting these bay'as, but nevertheless showed some caution. As early as November 2014, IS made its first round of acceptances, welcoming to its fold five jihadi groups form the Middle East. Not all bay'as were accepted, though. For instance, bay'as from Sinai, Libya, Yemen, Algeria, and the Arabian Peninsula (Saudi Arabia) resulted in the creation of wilayats (provinces), while in Caucasus and Khorasan (Af-Pak) they were delayed and other ba'yas were accepted, but not considered for official expansion (Dabiq 2014, p. 24). To justify the delays in accepting bay'as from some groups, IS put forward specific preconditions for the creation of new wilayats: unification of the jihadi forces operating in the area, nomination of a leader, a detailed plan of military conquest and submission of the 'file' to IS's central authorities for evaluation and approval (Dabiq 2015b, p. 35). These preconditions seemed to favor groups with established presence in their region, which had relatively fair chances to survive the aftermath of the bay'a.

Although IS's desire to affiliate with established groups that have operational potential is a plausible explanation, it fails to explain why the bay'a of practically non-existent groups in Algeria and Saudi Arabia was accepted in the first place. It appears more probable that expansion into Saudi Arabia was mainly guided by religious justifications and it was decided in the spirit of IS competition with al-Qaeda. In Algeria, the main motive might have been a desire to stir things within al-Qaeda in

2 Although the exact meaning of bay'a is not clear, it is used to denote a pledge of allegiance and submission to a person of authority. Originally it referred to allegiance to a Caliph (and the Prophet Muhammad himself), but later it was used more loosely. For more on this topic see (Milton and Al-Ubaydi 2015; Porter 2015; Wagemakers 2015). 
Islamic Maghreb (AQIM) and encourage possible defectors. It is equally noteworthy that none of the bay'as made by non-Arab groups were granted affiliation in this first round of acceptances (Milton and Al-Ubaydi 2015, p. 4). The first non-Arab wilaya was established in early 2015 in Af-Pak borderland (Khorasan Province), further highlighting the anti-al-Qaeda reasoning in IS's strategic planning. It is possible, then, that IS opted to begin its expansion with groups that, on the one hand, are smaller but possibly easier to manage (Milton and Al-Ubaydi 2015, pp. 4-5) and, on the other hand, are closer to its Syria/Iraq heartland, and possibly offer better communication channels. In 2015, IS confidence in its global aspirations grew as a result of the increasing tempo of attacks in western countries by small groups or individuals, who pledged bay'a to al-Baghdadi. This new-found confidence prompted IS to enlarge the circle of affiliates and include groups outside MENA.

IS's motivation to seek alliances in the jihadi movement seems rather straightforward. IS sought to create an arc of affiliates to claim a hegemonic role within the jihadi scene. IS expects little from its affiliates. Contrary to al-Qaeda that anticipated its affiliates to shift their priorities from local issues to fighting the far enemy, IS is content to leave its affiliates alone (Zelin 2015, p. 25). They are expected to operate under the banner of IS and they are expected to survive. In the best case scenario, these alliances might also convey logistical benefits to IS, such as streamlining fighters to Syria/Iraq (Milton and Al-Ubaydi 2015, p. 5). Apart from that, IS affiliates were free to organize their activity as they pleased.

Given that IS asked little from its affiliates, it is important to explore what IS offered in return. In other words, if alliances require a degree of need fulfilment on both sides, what the groups that pledged bay'a to IS expected from this affiliation. Their motivations run across the resources-ideology spectrum. Some groups were genuinely excited by the reestablishment of the caliphate (McCants 2016, p. 21). In this sense, they were driven by ideological considerations. These considerations occasionally stemmed from the local circumstances each group faced. The Islamic Movement of Uzbekistan (IMU) is an interesting example in this regard. Affiliated with al-Qaeda, but in close proximity to the Taliban, the foreign status of IMU in Af-Pak and its conflicts rendered the idea of IS borderless jihad more suited to IMU's goals than Taliban's nationalist aspirations (Jadoon 2018, p. 38).

In terms of resources-related motivations, some groups might have pledged allegiance to IS expecting financial rewards (Jadoon 2018, p. 32) or boosts in recruitment from the media attention their bay'a generated. IMU again is a case in point. Long detached from its main area of operations in Uzbekistan, IMU hoped that affiliation with IS will revive its influence within Uzbekistan and increase recruitment (Jadoon 2018, p. 38). Boko Haram also expected to attract more recruits from other West African countries and the diaspora, and possibly a better and wealthier pool of recruits beyond the 'poor al-majiri boys' profile of most Boko Haram's members (Zenn 2015, p. 21). Resources-related motivations were more central in low-end-operational-cooperation between IS and local groups, which expressed support but did not pledge bay'a to al-Baghdadi. This is most evident in Pakistan, where IS developed cooperative relations and conducted joint attacks with powerful groups, which did not fully share IS ideology, such as Lashkar-e-Islam (LeI), Jamaat-ul-Ahrar (JuA), Jundullah and the Balochistan National Army (Jadoon 2018, pp. 38-39; Rassler 2015, p. 9). Other groups might have been lured by the prospect of having access to IS's media apparatus, especially if they lacked a propaganda production mechanism of their own. IS-affiliated groups in Somalia are such an example. Although Al-Shabaab retained control of its very prolific media apparatus, the former al-Shabaab groups that pledged allegiance to IS could rely on IS central's media mechanism to produce and distribute their photos and videos from Somalia (Warner and Weiss 2017, p. 31). Boko Haram is also one of the organizations that benefited from better media production after their affiliation with IS (Milton and Al-Ubaydi 2015, p. 6).

While resources-related drivers varied across specific cases, a motivation shared by almost all groups was increased (local) political relevance (Jadoon 2018, p. 32). The motivation was particularly strong in groups operating in competitive jihadi environments. This quest for local power and relevance was only marginally related to the al-Qaeda-IS competition, but it was exceptionally destructive for 
local conflicts. It is no surprise, then, that most of the groups that pledged allegiance to IS were splinter-groups or factions from established (often al-Qaeda affiliated) organizations (Crone 2017, p. 69; McCants 2016, p. 21) These internal splits unwounded along old cleavages, regional differences or preexisting leadership disputes. They rested on divergences over interests and strategy or sometimes belied a more personal grudge, such as being overlooked in a promotion or stripped of personal fiefdoms. A case in point is the IS affiliate in Af-Pak, which attracted militants, who were unhappy with Taliban's peace negotiations with the government in Kabul. At the same time, the founders of the Khorasan Province were often passed over for leadership roles or profitable postings by the Taliban leadership (Rassler 2015, pp. 7-8; Sheikh 2017, p. 43). In the same vein, AQAP militants in Yemen, who broke away to form the IS-Yemen Province, accused AQAP that it was not doing enough to kill Shi'a Houthis (McCants 2016, p. 21). The case of AQAP also highlights the role of generational divides in movement fragmentation, as IS ideology has attracted primarily younger members of AQAP (Clausen 2017, p. 59).

In several cases geographical dispersal attenuated preexisting cleavages, festering poor communication and increasing intra-movement suppression costs. This is best evident in Somalia. Two factions split from al-Shabaab to join IS, one in northern Puntland region and the other in southern Somalia. The former, which is led by Abdulqadir Mumin, is the official IS branch in the region. It has also been the most active, with its biggest achievement being the brief capture of the port town of Qandala in Puntland (Weiss 2019, p. 29). The southern faction has been less formalized and less active. Yet, it has been the primary target of al-Shabaab efforts to stifle internal dissent. Al-Shabaab employed its internal security service, the Amniyat, to arrest and occasionally execute pro-IS members, but due to geographical distance from the Mumin-led Puntland group, it could only deploy it against the much more accessible southern factions (Warner and Weiss 2017, pp. 28-29). Likewise, Taliban were in a striking distance from IMU in Afghanistan. Thus, when IMU's leader Usman Ghazi pledged allegiance to al-Baghdadi, in the wake of the confirmation of Mullah Omar's death, Taliban could reach and defeat the Ghazi faction in November 2015, prompting some IMU members, who had followed Ghazi, to return to their fold (Jadoon 2018, pp. 37-38).

Weakness, as result of increased (state) counter-insurgency and military setbacks, has been at the core of some splits. For example, Egyptian army's crackdown in Sinai, in the wake of Morsi's ousting, possibly pushed Ansar Bayt al-Maqdis to make bay'a to IS (Lahoud 2015, p. 14). Likewise, the operations of the Pakistani army in the Federally Administered Tribal Areas (FATA) have been central motivation for the Orakzai and Bajaur factions of Tehrik-i-Taliban Pakistan (TTP) to switch allegiance to IS (Jadoon 2018, p. 36). Military pressure and weakness have also played a role in the case of Boko Haram. The large-scale military offensive, launched in February 2015, by Nigeria and neighboring countries (Chad, Cameroon and Niger) severely restrained Boko Haram (Crone 2017, p. 68; Cummings 2017, p. 24). Facing military setbacks and territorial losses, Boko Haram needed IS's global brand to project local relevance.

The previous discussion revealed a complex web of motivations, needs and strategic considerations behind the alliances that IS forged across the jihadi sub-system. These alliances materialized because they fulfilled some needs on both sides. Local groups benefited from media exposure, possible recruitment boosts, increased political relevance and opportunities to settle local scores with their mother-organizations. IS, on the other hand, was content with 'expanding' its global brand and solidifying its claim to hegemony within the jihadi subsystem. They did not compete directly for the same resources. Hence, they could take advantage of the benefits alliances offered without enduring the cost.

\section{Conclusions}

The meteoric rise of ISIS, in 2014, has taken the world by surprise. After being nearly decimated in the end of 2000s, the former al-Qaeda affiliate managed to break through the Iraqi borders and at its height control territory of a significant size. The article demonstrated that the ripples of IS's rise were 
felt across the international system and the jihadi subsystem. The declaration of the 'Caliphate' and al-Baghdadi's claim to the role of Caliph raised important questions regarding IS's interaction with the international order and the jihadi movement. The answers to these questions help us understand the true nature of IS's challenge and that of other groups that might try to emulate IS's paradigm in the future.

The article showed that, from mid-2014 until 2016, IS was by all accounts a de facto state, which though did not perceive itself as territorially bounded. Contrary to past examples of revolutionary states, it had no intention to fully 'socialize' in the system's norms and logic because it negated the premises of the Westphalian system, which contravenes the notion of a united ummah. Therefore, it does not see itself as part of and does not have any commitments towards the international community. All states but the 'Islamic State' are considered illegitimate and IS can offer them nothing more than a temporary truce. In this regard, by demanding the recognition of its supreme authority as a Caliphate, IS cannot succumb to the structural pressures to become a 'normal' state, without compromising its global brand. IS's extremism informed the discussion around possible strategies to counter its territorial growth and appeal. Although there were some proponents of a containment strategy, which rested on the idea that it is better to allow IS to fail rather than forcibly dismantle it, the international coalition opted for an active destruction strategy, assuming that containment would require time that, in light of IS's terrorist attacks and increasing refugee flows, was not available.

Concerns around its global brand do not only affect IS's authority and interaction with the international-Westphalian-system, but also the jihadi (sub)system. IS operates in a competitive jihadi market, which forces groups to preserve their ideological edge to keep competition in check and attract more fighters and resources than their competitors. By the same token, the article claims that, above all, IS's rise constitutes a bid for increased power and influence vis-à-vis rival Islamist groups. By being the first one to venture building an 'Islamic State' of this magnitude and Islamic connotations, IS poses a direct challenge to other groups within the jihadi sub-system. The challenge is most direct towards the other jihadi claimant to a global brand, al-Qaeda. Al-Baghdadi assumed that al-Qaeda no longer fulfilled ISI's needs and that, after bin Laden's death, there was room for a new brand. At the same time, the diminishing levels of trust and communication, both exacerbated by geographic distance, deepened the rift. Access to new resources and recruitment opportunities in the Syrian conflict, offered ISIS the additional material incentives to disassociate itself from al-Qaeda.

Drawing on Watts's (2016) exploration of IS-al-Qaeda competition, the article shows that IS-al-Qaeda rivalry has taken the form of 'destructive' and 'escalating competition'. However, contrary to Watts, the article posits that destructive competition, in terms of direct conflict between al-Qaeda and ISIS has been in reality limited, even in Syria, where the two groups were in direct contact. Apart from some skirmishes and localized fighting, the lion's share of anti-ISIS violence came from local jihadi forces. Although the jihadi movement traditionally suffers from weak institutions, high-level fighting between al-Qaeda and IS did not materialize, largely because the al-Qaeda leadership decided to keep a conciliatory tone in its 'war of words' against IS. At the same time, although ISIS often flirted with the notion of takfir against al-Qaeda, it crossed the line only in the end of 2015, when intra-jihadi fighting in Syria had largely ceased and the competition had shifted to global outbidding.

Instead, as the article shows, the rivalry between the two has been played out in three domains: propaganda, attacks on western targets and a 'war of bay'as'. The article, which mainly focuses on the latter, shows that the rift between al-Qaeda and IS forced prominent ideologues and jihadi groups around the world to situate themselves on the new jihadi map, either reiterating their loyalty to al-Qaeda or siding with the new-comer. This resulted in a flurry of competitive pledges of oath coming from all the corners of the jihadi movement. By initiating this 'war of bay'as' IS sought to create an arc of affiliates to claim a hegemonic role within the jihadi scene. IS expected little from its affiliates and gave little in return. Contrary to al-Qaeda, which expected its affiliates to fight the far enemy, IS was content to leave its affiliates to fight their local battles. Given that IS lacked the capacity to physically reach the entire umma, it chose to forge alliances with local same-minded forces that 
will carry its banner to the most remote corners of the umma. IS's international alliances materialized because IS and its affiliates do not compete in the same political and resource market.

In local contexts, however, the IS-al-Qaeda competition generated a cycle of intra-field rivalries and fragmentation. Most of the groups that pledged allegiance to IS were splinter-groups from established (often al-Qaeda affiliated) organizations. This local intra-field competition unwounded along old cleavages, regional differences or preexisting leadership disputes. In several cases geographical dispersal attenuated preexisting cleavages, festering poor communication and increasing intra-movement suppression costs. The motivations of local jihadi groups that pledged bay'a to IS run across the resources-ideology spectrum. Some groups were genuinely excited by the reestablishment of the caliphate, while others were driven by organizational concerns and (tangible and intangible) resources-related considerations, as the relevant scholarship predicts. Weakness, as result of increased (state) counter-insurgency and military setbacks, has been also at the core of some splits. A motivation shared by almost all groups was local political relevance and influence, especially for groups operating in competitive jihadi environments. This quest for local power and relevance was only marginally related to the al-Qaeda-IS competition, but it was exceptionally destructive for local conflicts.

Some alliances proved successful and lasting, while others, although announced with many hopes, were born stillborn (e.g., Algeria, Tunisia) or were quickly subsumed by their early successes (e.g., Libya and to some extent Yemen). IS's territorial losses in Syria and Iraq has taken a serious blow to IS brand. However, despite losing its capacity to 'remain', which has been the centerpiece of IS propaganda, IS manages to preserve most of its affiliates. The assassination of al-Baghdadi served an additional blow to IS, largely because the IS brand was built on a personality cult around al-Baghdadi. This renders the effort of his successor, Abu Ibrahim al-Hashimi al-Qurashi, to solicit support and authority harder (Bunzel 2019). Nevertheless, al-Baghdadi's death has instigated a flow of bay'a renewals from official wilayat and affiliated groups (Zelin 2019), demonstrating that IS, although severely weakened, remains relevant.

Funding: This research received no external funding

Conflicts of Interest: The author declares no conflict of interest.

\section{References}

Adamson, Fiona B. 2005. Globalisation, Transnational Political Mobilisation, and Networks of Violence. Cambridge Review of International Affairs 18: 31-49. [CrossRef]

Al-Adnani, Abu Muhammad. 2014. This Is the Promise of Allah. Global Terrorism Research Project: Islamic State. Available online: https://scholarship.tricolib.brynmawr.edu/bitstream/handle/10066/14242/ADN20140629. pdf? sequence $=1$ (accessed on 5 January 2020).

Al-Adnani, Abu Muhammad. 2016. And Those Who Lived [in Faith] Would Live Upon Evidence, (Audio and Transcript). Available online: https://www.memri.org/tv/isis-spokesman-abu-muhammad-al-adnani-callssupporters-carry-out-terror-attacks-europe-us (accessed on 23 March 2020).

Al-Shishani, Murad Batal. 2014. The Islamic State's Strategic and Tactical Plan for Iraq. Terrorism Monitor 12: 6-7.

Armstrong, David. 1993. Revolution and World Order: The Revolutionary State in International Society. Oxford: Clarendon Press.

Asal, Victor H., and R. Karl Rethemeyer. 2008. The Nature of the Beast: Terrorist Organizational Characteristics and Organizational Lethality. Journal of Politics 70: 437-49. [CrossRef]

Asal, Victor H., Gary A. Ackerman, and R. Karl Rethemeyer. 2012. Connections Can Be Toxic: Terrorist Organizational Factors and the Pursuit of Cbrn Weapons. Studies in Conflict E Terrorism 35: 229-54.

Asal, Victor H., Hyun Hee Park, R. Karl Rethemeyer, and Gary Ackerman. 2016. With Friends Like These ... Why Terrorist Organizations Ally. International Public Management Journal 19: 1-30. [CrossRef]

Bacon, Tricia. 2014. Alliance Hubs: Focal Points in the International Terrorist Landscape. Perspectives on Terrorism 8: 4-26.

Bacon, Tricia. 2018. Is the Enemy of My Enemy My Friend? How Terrorist Groups Select Partners. Security Studies 27: 345-78. [CrossRef] 
Bakke, Kristin M., Kathleen Gallagher Cunningham, and Lee J. M. Seymour. 2012. A Plague of Initials: Fragmentation, Cohesion, and Infighting in Civil Wars. Perspectives on Politics 10: 265-83. [CrossRef]

Bapat, Navin A., and Kanisha D. Bond. 2012. Alliances between Militant Groups. British Journal of Political Science 42: 793-824. [CrossRef]

Barnett, Michael N. 1996. Identity and Alliances in the Middle East. In The Culture of National Security: Norms and Identity in World Politics. Edited by Peter Katzenstein. New York: Columbia University Press, pp. 400-47.

Bloom, Mia. 2005. Dying to Kill: The Allure of Suicide Terror. New York: Columbia University Press.

Brachman, Jarret M., and William McCants. 2006. Stealing Al-Qa'ida's Playbook. West Point: Combating Terrorism Center at West Point.

Brown, Vahid. 2007. Cracks in the Foundation: Leadership Schisms in Al-Qa'ida 1989-2006. West Point: Combating Terrorism Center at West Point.

Bunzel, Cole. 2014. The Islamic State of Disunity: Jihadism Divided. Jihadica. Available online: http: //www.jihadica.com/the-islamic-state-of-disunity-jihadism-divided/ (accessed on 30 January 2020).

Bunzel, Cole. 2015. From Paper State to Caliphate: The Ideology of the Islamic State. Washington: Center for Middle East Policy, Brookings.

Bunzel, Cole. 2019. Caliph Incognito: The Ridicule of Abu Ibrahim Al-Hashimi. Jihadica. Available online: https://www.jihadica.com/caliph-incognito/ (accessed on 25 January 2020).

Byman, Daniel. 2014. Buddies or Burdens? Understanding the Al Qaeda Relationship with Its Affiliate Organizations. Security Studies 23: 431-70. [CrossRef]

Christia, Fotini. 2012. Alliance Formation in Civil Wars. Cambridge: Cambridge University Press.

Clausen, Maria-Louise. 2017. Islamic State in Yemen-a Rival to Al-Qaeda? Connections 16: 50-62. [CrossRef]

Conrad, Justin, and Kevin Greene. 2015. Competition, Differentiation, and the Severity of Terrorist Attacks. The Journal of Politics 77: 546-61. [CrossRef]

Cragin, Kim, Peter Chalk, Sara A. Daly, and Brian A. Jackson. 2007. Sharing the Dragon's Teeth: Terrorist Groups and the Exchange of New Technologies. Santa Monica: Rand Corporation.

Crone, Manni. 2017. Islamic State's Incursion into North Africa and Sahel: A Threat to Al-Qaeda? Connections 16: 63-76. [CrossRef]

Cummings, Ryan. 2017. A Jihadi Takeover Bid in Nigeria? The Evolving Relationship between Boko Haram and Al-Qa'ida'. CTC Sentinel 10: 24-29.

Dabiq. 2014. Remaining and Expanding. Vol. 5, al-Hayat Media Center: Islamic State.

Dabiq. 2015a. Just Terror. Vol. 12, al-Hayat Media Center: Islamic State.

Dabiq. 2015b. From Hypocrisy to Apostasy: The Extinction of the Grayzone. Vol. 7, al-Hayat Media Center: Islamic State.

Dabiq. 2015c. From the Battles of Al-Ahzāb to the War of Coalitions. Vol. 11, al-Hayat Media Center: Islamic State.

Dabiq. 2015d. Shari'ah Alone Will Rule Africa. Vol. 8, al-Hayat Media Center: Islamic State.

Fearon, James D. 1995. Rationalist Explanations for War. International organization 49: 379-414. [CrossRef]

Gade, Emily Kalah, Michael Gabbay, Mohammed M. Hafez, and Zane Kelly. 2019. Networks of Cooperation: Rebel Alliances in Fragmented Civil Wars. Journal of Conflict Resolution 63: 2071-97. [CrossRef]

Hafez, Mohammed M. 2017. Fratricidal Rebels: Ideological Extremity and Warring Factionalism in Civil Wars. Terrorism and Political Violence, 1-26. [CrossRef]

Hagerty, Vivian G. 2016. Terrorist Divorce: Examining Alliance Break-Ups and the Al Qaeda/ISIL Split. Clocks and Clouds 6: 1-22.

Halliday, Fred. 1999. Revolution and World Politics: The Rise and Fall of the Sixth Great Power. London: Macmillan Press. Hamming, Tore Refslund. 2017. Jihadi Competition and Political Preferences. Perspectives on Terrorism 11: 63-88.

Hamming, Tore Refslund. 2019. Polemical and Fratricidal Jihadists: A Historical Examination of Debates, Contestation and Infighting within the Sunni Jihadi Movement. London: The International Centre for the Study of Radicalisation and Political Violence (ICSR).

Hamming, Tore Refslund. 2020. The Al Qaeda-Islamic State Rivalry: Competition Yes, but No Competitive Escalation. Terrorism and Political Violence 32: 20-37. [CrossRef]

Hassan, Hassan. 2018. Two Houses Divided: How Conflict in Syria Shaped the Future of Jihadism. CTC Sentinel 11: $1-8$.

Holsti, Ole R., P. Terrence Hopmann, and John D. Sullivan. 1973. Unity and Disintegration in International Alliances: Comparative Studies. New York: Wiley. 
Holtmann, Philipp. 2014. The Different Functions of IS Online and Offline Plegdes (Bay'at): Creating a Multifaceted Nexus of Authority. Jihadology. Available online: https://jihadology.net/2014/11/15/guest-post-the-differentfunctions-of-is-online-and-offline-plegdes-bayat-creating-a-multifaceted-nexus-of-authority/ (accessed on 23 January 2020).

Horowitz, Michael C. 2010. Nonstate Actors and the Diffusion of Innovations: The Case of Suicide Terrorism. International Organization 64: 33-64. [CrossRef]

Horowitz, Michael C., and Philip B. K. Potter. 2014. Allying to Kill: Terrorist Intergroup Cooperation and the Consequences for Lethality. Journal of Conflict Resolution 58: 199-225. [CrossRef]

Jabareen, Josef. 2015. The Emerging Islamic State: Terror, Territoriality, and the Agenda of Social Transformation. Geoforum 58: 51-55. [CrossRef]

Jackson, Kevin. 2014. Al-Qaeda Revives Its Beef with the Islamic State. Jihadica. Available online: http: //www.jihadica.com/al-qaeda-revives-its-beef-with-the-islamic-state/ (accessed on 25 January 2020).

Jadoon, Amira. 2018. Allied and Lethal: Islamic State Khorasan's Network and Organizational Capacity in Afghanistan and Pakistan. West Point: Combating Terrorism Centre at West Point.

Jones, Seth G., James Dobbins, Daniel Byman, Christopher S. Chivvis, Ben Connable, Jeffrey Martini, Eric Robinson, and Nathan Chandler. 2017. Rolling Back the Islamic State. Santa Monica: Rand Corporation.

Kalyvas, Stathis N., and Matthew Adam Kocher. 2007. How “Free” Is Free Riding in Civil Wars?: Violence, Insurgency, and the Collective Action Problem. World Politics 59: 177-216. [CrossRef]

Karmon, Ely. 2005. Coalitions between Terrorist Organizations: Revolutionaries, Nationalists and Islamists. Leiden: Martinus Nijhoff Publishers.

Lahoud, Nelly, Stuart Caudill, Liam Collins, Gabriel Koehler-Derrick, Don Rassler, and Muhammad Al-Ubaydi. 2012. Letters from Abbottabad: Bin Ladin Sidelined? West Point: Combating Terrorism Center at West Point.

Lahoud, Nelly, and Muhammad Al-Ubaydi. 2014. The War of Jihadists against Jihadists in Syria. CTC Sentinel 7: $1-6$.

Lahoud, Nelly. 2015. The Province of Sinai: Why Bother with Palestine If You Can Be Part of the 'Islamic State'? CTC Sentinel 8: 12-14.

Lia, Brynjar. 2015. Understanding Jihadi Proto-States. Perspectives on Terrorism 9: 31-41.

Maoz, Zeev. 1996. Domestic Sources of Global Change. Ann Arbor: University of Michigan Press.

McCants, William. 2016. The Polarizing Effect of Islamic State Aggression on the Global Jihadist Movement. CTC Sentinel 9: 20-23.

Milton, Daniel, and Muhammad Al-Ubaydi. 2015. Pledging Bay'A: A Benefit or Burden to the Islamic State? CTC Sentinel 8: 1-7.

Moghadam, Assaf, and Brian Fishman. 2010. Self-Inflicted Wounds: Debates and Divisions within Al-Qa'ida and Its Periphery. West Point: Combating Terrorism Center at West Point.

Moghadam, Assaf. 2015. Terrorist Affiliations in Context: A Typology of Terrorist Inter-Group Cooperation. CTC Sentinel 8: 22-25.

Moghadam, Assaf. 2017. Nexus of Global Jihad: Understanding Cooperation among Terrorist Actors. New York: Columbia University Press.

Nemeth, Stephen. 2014. The Effect of Competition on Terrorist Group Operations. Journal of Conflict Resolution 58: 336-62. [CrossRef]

Nesser, Petter, Anne Stenersen, and Emilie Oftedal. 2016. Jihadi Terrorism in Europe: The Is-Effect. Perspectives on Terrorism 10: 3-24.

Nesser, Petter. 2019. Military Interventions, Jihadi Networks, and Terrorist Entrepreneurs: How the Islamic State Terror Wave Rose So High in Europe. CTC Sentinel 12: 15-21.

Oots, Kent Layne. 1989. Organizational Perspectives on the Formation and Disintegration of Terrorist Groups. Studies in Conflict E Terrorism 12: 139-52.

Phillips, Brian J. 2019. Terrorist Group Rivalries and Alliances: Testing Competing Explanations. Studies in Conflict $\mathcal{E}$ Terrorism 42: 997-1019.

Porter, Geoff D. 2015. What to Make of the Bay 'a in North Africa? CTC Sentinel 8: 14-6.

Posen, Barry R. 1993. The Security Dilemma and Ethnic Conflict. Survival 35: 27-47. [CrossRef]

Rassler, Don. 2015. Situating the Emergence of the Islamic State of Khorasan. CTC Sentinel 8: 7-11.

Rich, Paul B. 2016. How Revolutionary Are Jihadist Insurgencies? The Case of ISIL. Small Wars E Insurgencies 27: 777-99. 
Sheikh, Mona Kanwal. 2017. Islamic State Enters Al-Qaeda's Old Hotbed: Afghanistan and Pakistan. Connections 16: 37-49. [CrossRef]

Skovgaard-Petersen, Jakob. 2017. Heirs of Abu Bakr: On the Ideology and Conception of History in Al-Qaeda and Islamic State. Connections 16: 25-36. [CrossRef]

Staniland, Paul. 2012. Between a Rock and a Hard Place: Insurgent Fratricide, Ethnic Defection, and the Rise of Pro-State Paramilitaries. Journal of Conflict Resolution 56: 16-40. [CrossRef]

Vu, Tuong, and Patrick Van Orden. 2019. Revolution and World Order: The Case of the Islamic State (ISIS). International Politics 57: 57-78. [CrossRef]

Wagemakers, Joas. 2015. The Concept of Bay 'a in the Islamic State's Ideology. Perspectives on Terrorism 9: 98-106. Walt, Stephen M. 1987. The Origins of Alliances. Ithaca: Cornell University Press.

Walt, Stephen M. 1992. Revolution and War. World Politics 44: 321-68. [CrossRef]

Walt, Stephen M. 1996. Revolution and War. New York: Cornell University Press.

Walt, Stephen M. 2015. ISISs as Revolutionary State. Foreign Affairs 94: 42-51.

Warner, Jason, and Caleb Weiss. 2017. A Legitimate Challenger? Assessing the Rivalry between Al-Shabaab and the Islamic State in Somalia. CTC Sentinel 10: 27-32.

Watts, Clint. 2015. Let Them Rot: The Challenges and Opportunities of Containing Rather Than Countering the Islamic State. Perspectives on Terrorism 9: 156-64.

Watts, Clint. 2016. Deciphering Competition between Al-Qa'ida and the Islamic State. CTC Sentinel 9: 1-6.

Weiss, Caleb. 2019. Reigniting the Rivalry: The Islamic State in Somalia Vs. Al-Shabaab. CTC Sentinel 12: 29-35.

Zelin, Aaron. 2015. The Islamic State's Model. In Islamism in the IS Age, 24-28: Project on Middle East Political Science (POMEPS). Available online: https://pomeps.org/wp-content/uploads/2015/03/POMEPS_Studies_12_ ISAge_Web.pdf (accessed on 17 January 2020).

Zelin, Aaron. 2019. The Islamic State's Bayat Campaign. Jihadology. Available online: https://jihadology.net/2019/ 11/03/the-islamic-states-bayat-campaign/ (accessed on 30 January 2020).

Zenn, Jacob. 2015. A Biography of Boko Haram and the Baya to Al-Baghdadi. CTC Sentinel 8: 17-21.

(C) 2020 by the author. Licensee MDPI, Basel, Switzerland. This article is an open access article distributed under the terms and conditions of the Creative Commons Attribution (CC BY) license (http://creativecommons.org/licenses/by/4.0/). 